\title{
DAYA MANGSA PREDATOR Harmonia axyridis TERHADAP KUTU DAUN Mizus persicae PADA TANAMAN JERUK
}

\author{
Predatory Prey of Harmonia axyridis against Mizus. persicae Aphids \\ on Citrus Plants
}

\author{
Otto Endarto $^{1 \mathrm{a}}$ dan Susi Wuryantini ${ }^{1}$ \\ ${ }^{1}$ Balai Penelitian Jeruk dan Buah Subtropika \\ Jl. Raya Tlekung 1, Junrejo, Kota Batu. \\ ${ }^{\text {a}}$ Korespondensi: Otto \\ Email: endarto11@gmail.com
}

\begin{abstract}
ABSTRAK
Penelitian bertujuan untuk mengetahui daya mangsa dan preferensi Harmonia axyridis terhadap kutu daun Mizus persicae pada tanaman jeruk selama satu siklus hidup dimulai dari larva instar pertama sampai imago. Penelitian dilakukan di Rumah Kasa dan Laboratorium Entomologi Balai Penelitian Tanaman Jeruk dan Buah Sub Tropika, pada bulan Januari- Maret 2016. Daya mangsa menggunakan stadia larva pertama $H$. axyridis sampai imago sebanyak 30 ekor setiap arena percobaan. Data dianalisis dengan menghitung rata-rata kutu daun $M$. persicae yang dimangsa per hari dari masing-masing instar larva dan imago $H$. axyridis serta menghitung rata-rata yang dimangsa dari seluruh siklus hidupnya. Hasil penelitian menunjukkan daya mangsa tertinggi $H$. axyridis terjadi pada larva instar 4, yang mencapai 428,3\% dari bobot tubuhnya, dengan jumlah mangsa 9,81 $\pm 1,01$ ekor/hari. Preferensi $H$. axyridis pada stadia larva instar 1,2, dan 3 adalah nimfa instar 1 dari $M$. persicae, dan untuk $H$. axyridis larva instar 4 dan imago lebih menyukai nimfa instar 4. $H$. axyridis mempunyai siklus hidup dengan kisaran 6,6-9,7 hari. Lama stadia telur $H$. axyridis 3 hari, larva terdiri atas 4 instar, lama stadia masing-masing instar adalah selama 2,4 hari untuk instar 1 dan 2, 5 hari untuk instar 3, 12 hari untuk instar 4, dan 18,5 hari untuk imago.
\end{abstract}

Kata kunci: Daya mangsa, predator Harmonia axyridis, kutu daun Mizus persicae, jeruk

\begin{abstract}
The research aims to determine the prey abilily and preferences of Harmonia axyridis against Mizus persicae on citrus. The study was conducted at the screen house and Entomology Laboratory of the Research Institute for Citrus and Sub-Tropical Fruits, in January-March 2016. The test for prey ability used the first larval stage of $H$. axyridis to imago for 30 individuals in each arena. Data were analyzed by counting of $M$. persicae which eaten per day from each stage, i.e. larva instar, and H. axyridis imago, as well as the average prey during their life cycle. The results showed that the highest prey of $H$. axyridis occurred in instar larvae 4, which reached $428.3 \%$ of is body weight, with a number of preys $9.81 \pm 1.01$ head/day. Preferences of H. axyridis in instars larvae 1,2, and 3 were instar nymphs 1 from $M$. persicae, and for $H$. axyridis the instar larvae 4 and imago preferred of instar nymph 4. H. axyridis had a life cycle with a range of 6.6 -9.7 days. The duration of egg stage of the $H$. axyridis was 3 days, the larvae consisted of 4 instars, the duration of the stage for each instar was 2.4 days for instar 1 and 2; 5 days for instar 3; 12 days for instar 4, and 18.5 days for imago.
\end{abstract}

Keywords: Prey, predator Harmonia axyridis, Mizus persicae, citrus 


\section{PENDAHULUAN}

Serangga yang merugikan bagi manusia salah satunya yaitu kutu daun Myzus persicae yang merupakan famili Aphididae. Hama ini berbeda dengan serangga lainnya dalam berkembang biak, yaitu dengan melahirkan anaknya, dan termasuk serangga yang vivipar partenogenesis atau baik jantan maupun betinanya melahirkan anak. Pada saat imago $M$. persicae dapat bersayap maupun tidak bersayap. Hama ini menyerang dan mengakibatkan kerusakan pada daun jeruk dengan cara menghisap cairan daun muda dan bagian tanaman yang masih muda (tunas pucuk). Akibat yang ditimbulkan dari hama ini menyebabkan tanaman menjadi keriput, tumbuh kerdil, warna daun kekuningan, terpuntir, layu dan mati. Selain itu M. persicae dapat menyebabkan kerusakan yang berarti pada tanaman, yaitu sebagai vektor virus Tristeza, yang menyebabkan kerugian ekonomi relatif Ditlin 2008).

Usaha pengendalian serangga hama dengan cara kimiawi merupakan cara yang paling banyak dilakukan oleh petani. Cara pengendalian tersebut dapat menimbulkan beberapa dampak yang merugikan, yaitu: adanya peledakan hama sekunder (resurgensi), resistensi hama terhadap pestisida, matinya musuh alami, mencemari dan merusak lingkungan serta membahayakan bagi manusia. Untuk mengurangi dampak negatif akibat penggunaan pestisida kimiawi, maka dikembangkan cara pengendalian hama yang ramah lingkungan, yaitu secara hayati. Pengendalian hayati menurut Untung (2006), merupakan cara pengelolaan hama yang dilakukan secara sengaja memanfaatkan atau memanipulasikan musuh alami untuk menurunkan atau mengendalikan populasi hama.

Beberapa serangga dari famili Coccinellidae dalam bentuk dewasa maupun larva dapat bertindak sebagai predator (Anonymous $2008^{\mathrm{b}}$ ), sehingga keberadaanya mampu berperan dalam mengendalikan hama tanaman pertanian. Salah satu famili Coccinellidae yang berperan sebagai musuh alami pada tanaman jeruk adalah Harmonia axyridis Pallas. Perkembangan dilapang sangat tergantung dari penggunaan pestisida, artinya bahwa stadia imago merupakan stadia yang lebih tahan dibandingkan dengan stadia larva (Ahn et al., 2001, Michaud, 2002., Cho et al., 2002).

Predator ini telah diperkenalkan sebagai musuh alami di Asia Barat, tahun 1916 diintroduksi ke California, Amerika Serikat, dan pada tahun 1978 dan 1982 menyebar ke sebelah Timur Amerika Serikat. Pada tahun 1997, H. axyridis menggantikan Coccinella septempunctata sebagai agen hayati dari Aphis spiraecola disebelah Timur Virginia Barat (Sitrianingsih 2008). Berdasarkan hasil penelitian Koch (2003), serangga ini merupakan predator dari berbagai macam Aphid. Selain itu, juga mampu memangsa famili dari Tetranichidae, Coccoidea, Crysomelidae, Curculionidae dan Lepidoptera. Salah satunya yaitu Harmonia axyridis yang termasuk predator paling berpotensi dan berkembang di Asia (Hukusima , 1972).

Menurut hasil penelitian Kevin dan Neil (2004), H. axyridis mampu mengkonsumsi atau memangsa 15-65 aphid per hari, dan tiap larva dapat mengkonsumsi 90-370 aphid selama dalam perkembangannya. Hal ini menunjukkan $H$. axyridis potensial sebagai agen pengendali biologi serangga hama pada tanaman pertanian, Sabaey (1999), He et al. (1994), Soares et al. (2001), dalam Koch (2003), menunjukkan bahwa $H$. axyridis umumnya hidup antara 30-90 hari bergantung pada temperatur.

Kemampuan $H$. axyridis dalam memangsa kutu daun $M$. persicae belum banyak diketahui selama satu siklus hidupnya, sehingga perlu dilakukan penelitian tentang Kajian Aspek Biologi dan Daya Mangsa Harmonia axyridis Pallas terhadap Kutu Daun Myzus persicae Sulz pada Tanaman Jeruk (Citrus sp).

\section{BAHAN DAN METODE}

Penelitian ini dilaksanakan mulai bulan Januari-Maret 2016, bertempat di laboratorium Entomologi Balai Penelitian Tanaman Jeruk dan Buah Subtropika (BALITJESTRO), Jl. Raya Tlekung No.1 Junrejo-Kota Batu- Jawa Timur. 
Alat yang digunakan pada penelitian ini antara lain wadah toples plastik, gelas plastik $(\mathrm{d}=3,5 \mathrm{~cm}$ dan $\mathrm{t}=4,5 \mathrm{~cm})$, kuas halus ukuran 000, mikroskop binokuler, timbangan analitik, kertas label, kamera, tissu, kain sifon + spon +kertas mika+ kastol (sebagai sangkar rearing $M$. persicae), nampan, dan savanna.

Bahan yang digunakan pada penelitian ini antara lain yaitu: $H$. axyridis, kutu daun $M$. persicae dan benih jeruk Japanse Citrus (JC) dalam polybag.

\section{Pelaksanaan Penelitian}

Harmonia axyridis Pallas. yang digunakan sebagai perlakuan adalah dari keturunan pertama (F1) sebanyak 30 ekor setiap arena percobaan. Pengamatan daya mangsa $H$. axyridis terhadap kutu daun $M$. persicae dengan tahapan sebagai berikut:

1. Harmoni axyridis ditimbang terlebih dahulu bobot tubuhnya, sebelum pengamatan daya mangsa (untuk penyesuaian pemberian pakan)

2. Pengamatan daya mangsa dilakukan dengan menggunakan stadia larva $H$. axyridis mulai instar I sampai imago sebanyak 30 ekor per perlakuan.

3. Perlakuan daya mangsa dilakukan dalam gelas plastik $(\mathrm{d}=3,5 \mathrm{~cm}$ dan $\mathrm{t}=4,5 \mathrm{~cm})$. Setiap gelas plastik diisi dengan 1 ekor $H$. axyridis.

4. Pemberian pakan dilakukan setiap hari dengan jumlah pakan $2 \mathrm{x}$ atau lebih dari berat tubuh $H$. axyridis dengan stadia campuran sebagai mangsanya, agar tidak kekurangan makanan.

5. Perlakuan daya mangsa dilakukan dengan interval pengamatan 24 jam.

6. Dihitung jumlah $M$. persicae yang telah dimangsa oleh stadia $H$. axyridis dengan cara mengurangi jumlah awal nimfa $M$. persicae yang diumpankan dengan jumlah sisa nimfa $M$. persicae yang dimangsa.

\section{HASIL DAN PEMBAHASAN}

\section{Daya mangsa, Harmonía axyridis Pallas terhadap kutu daun Myzus persicae Sulz}

Hasil penelitian menunjukkan bahwa daya mangsa $H$. axyridis Pallas terhadap kutu daun $M$. persicae Sulz, mulai stadia larva sampai imago pada $H$. axyridis terhadap kutu daun $M$. persicaeyata (Tabel 1).

Pengamatan daya mangsa ini dilakukan selama satu siklus hidup, yaitu mulai larva keluar dari telur sampai imago mati. Pengamatan daya mangsa dilakukan di

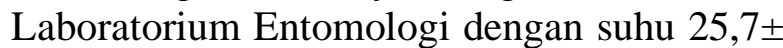
$1.1{ }^{0} \mathrm{C}$ dan kelembaban $89,3 \pm 6.8 \%$. Data yang dicantumkan pada Tabel 1, menunjukkan bahwa daya mangsa tertinggi selama satu siklus hidup terjadi pada stadia larva instar 4 yaitu rata-rata 9,81 \pm 1.01 ekor/hari. Daya mangsa tertinggi pada stadia 4 terjadi pada umur 17 hari sebelum memasuki stadia prapupa. Hal ini terjadi karena pada larva instar 4 volume tubuh semakin besar dan kebutuhan nutrisi semakin tinggi untuk menghadapi masa prepupa, sehingga jumlah mangsa yang dibutuhkan semakin banyak.

Dijelaskan oleh Prasetyo (2000), bahwa perbedaan kemampuan memangsa tersebut dipengaruhi oleh beberapa faktor antara lain oleh tingkat stadia, karena semakin besar ukuran tubuh maka semakin besar daya mangsa suatu serangga predator.

Pada penelitian Anwar et al. (1999), Joon-Ho Lee et al.(2004), menyatakan bahwa larva kumbang Coccinella arcuata $F$. lebih rakus memangsa kutu daun instar awal (larva) dibandingkan dengan imagonya. Hal ini karena pada masa larva tersebut membutuhkan nutrisi yang lebih banyak untuk pertumbuhan dan perkembanganya. Dipertegas oleh Wagiman (2006), semakin besar larva semakin meningkat kemampuan mangsanya. Selain itu ukuran dari predator dan mangsa juga akan mempengaruhi daya mangsa dari predator itu sendiri. Menurut Sands dan Simpson (1972) dalam Anwar et al. (1999) menyatakan bahwa predator Coccinellidae dalam mengkonsumsi kutu daun dipengaruhi oleh ukuran mangsa. Makin besar predator maka semakin banyak nimfa yang dimangsa karena nutrisi yang dibutuhkan semakin banyak. Pada Gambar 1, tampak jelas bahwa semakin panjang tubuh larva, maka kemampuan makannya semakin tinggi karena jumlah mangsa yang dimakannya semakin banyak. 
Tabel 1. Daya mangsa Harmonia axyridis mulai stadia larva sampai imago

\begin{tabular}{ccccc}
\hline No & $\begin{array}{c}\text { Instar } \\
\text { H.axyridis }\end{array}$ & $\begin{array}{c}\text { Jumlah } \\
\text { serangga uji }\end{array}$ & $\begin{array}{c}\text { Mangsa (ekor/instar) } \\
\text { Rata-rata } \pm \text { SD }\end{array}$ & $\begin{array}{c}\text { Mangsa (ekor/hari) } \\
\text { Rata-rata } \pm \text { SD }\end{array}$ \\
\hline 1 & I & 30 & $12,13 \pm 5,69(2$ hari $)$ & $5,10 \pm 2,26$ \\
2 & II & 30 & $15,57 \pm 9,14(2$ hari) & $6,28 \pm 2,37$ \\
3 & III & 30 & $31,36 \pm 13,56(5$ hari) & $7,52 \pm 2,75$ \\
4 & IV & 30 & $104,68 \pm 37,87(12$ hari) & $9,81 \pm 1,01$ \\
5 & Imago & 30 & $167,84 \pm 128,41$ (18 hari) & $7,42 \pm 2,63$ \\
\hline
\end{tabular}

\section{Daya Mangsa Predator $H$. axyridis terhadap Kutu Daun $M$. persicae}

Pengamatan daya mangsa $H$. axyridis selama stadia larva, dimulai dari awal stadia larva instar 1 dengan berat tubuh $0.0008 \mathrm{~g}$ mampu memangsa kutu daun $M$. persicae sebanyak 10 kali berat tubuhnya, dengan daya mangsa 5,10 $\pm 2,26$ ekor/hari (Tabel 1). Hal ini diduga pada larva instar 1 energi yang dibutuhkan tidak terlalu banyak, karena sesuai dengan ukuran tubuhnya. Sebagaimana diungkapkan oleh Tarumingkeng (2007), bahwa ukuran tubuh predator yang relatif kecil menyebabkan kebutuhan makannya juga relatif sedikit. Selanjutnya daya mangsa pada larva instar 2 mengalami peningkatan yaitu $6,28 \pm 2,37$ ekor/hari sebanyak 10 kali berat tubuhnya. Daya mangsa paling tinggi pada instar 2 terjadi pada hari ke 3. Hal ini disebabkan ukuran tubuh predator yang semakin besar sehingga daya mangsanya meningkat. Pernyataan ini didukung oleh Wagiman (2006), bahwa kemampuan memangsa larva predator coccinellid sebanding dengan ukuran tubuhnya, jadi semakin besar larva semakin meningkat kemampuan makannya, sebaliknya semakin kecil larva maka semakin menurun kemampuan mangsanya.

Larva instar 3 mengalami peningkatan daya mangsa yaitu 7,52 $\pm 2,75$ ekor/hari, dengan berat $0,0058 \mathrm{~g}$ mampu memangsa kutu daun $M$. persicae $232,29 \%$ dari berat tubuh. Selanjutnya larva instar 4 mengalami peningkatan yang sangat besar yaitu 9,81 $\pm 1,01$ ekor/hari (Tabel 1). Daya mangsa tertinggi pada larva instar 4 terjadi pada umur 17 hari sebelum memasuki stadia prepupa.
Hasil penelitian Xue et al. (2009) menyebutkan bahwa mulai instar ke $3, H$. axiridis mempunyai tingkat predasi yang cukup tinggi atau maksimal terhadap kutu daun pada tanaman kedelai.

Larva instar $4 H$. axyridis dengan berat tubuh 0,014g mampu memangsa kutu daun $M$. persicae $428.3 \%$ dari berat tubuh. Hal ini diduga pada larva instar 4 sebelum meletakkan abdomennya sendiri ke daun atau permukaan lain untuk pupa, membutuhkan nutrisi yang banyak untuk disimpan pada saat masa prepupa dan pupa. Pada masa prepupa dan pupa, H. axyridis akan inaktif dan tidak melakukan kegiatan memangsa, namun tetap membutuhkan nutrisi untuk pembentukan tubuh pada stadia berikutnya. Kondisi ini membuat $H$. axyridis sebelum memasuki tingkatan siklus hidup yang lebih tinggi akan memakan mangsa yang banyak yang nantinya dapat digunakan sebagai cadangan makanan selama masa inaktif.

\section{Daya Mangsa Predator $\boldsymbol{H}$. axyridis Stadia Imago terhadap Kutu Daun M. persicae}

Berdasarkan hasil pengamatan, imago dengan bobot tubuh 0,4166g mampu memangsa 7,42 $\pm 2,63$ ekor/hari. Hasil pengamatan daya mangsa imago $H$. axyridis menunjukkan bahwa, rata-rata daya mangsa tertinggi terletak pada umur 29 hari yaitu 13,15 $\pm 5,81$ ekor/hari (Gambar 1). Hal ini diduga karena pada saat ini imago sudah siap untuk berkopulasi. Dengan demikian imago membutuhkan nutrisi yang banyak untuk kematangan sel telur bagi yang betina dan sel sperma bagi yang jantan. 


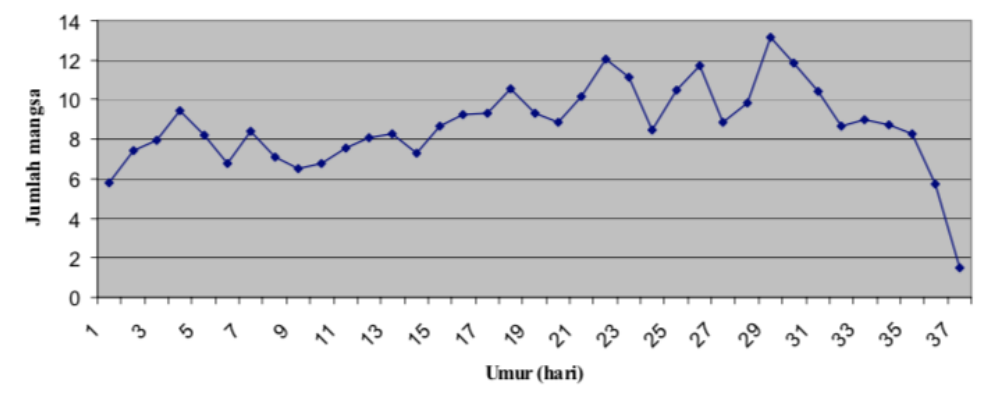

Gambar 1. Daya mangsa predator H. axyridis stadia imago terhadap kutu daun M. persicae.

Salah satu kandungan nutrisi yang berperan penting untuk reproduksi imago adalah protein. Protein digunakan untuk pematangan telur pada imago, sedangkan imago jantan membutuhkan protein untuk pematangan sperma (Nation 2002). Chapman (1998) menambahkan bahwa kualitas yang baik dari protein dan asam amino penting untuk pertumbuhan dan reproduksi.

\section{KESIMPULAN}

Berdasarkan hasil penelitian aspek biologi, daya mangsa Harmonia axyridis Pallas terhadap kutu daun Myzus persicae dan preferensi mangsa dari stadia $H$. axyridis, dapat disimpulkan bahwa siklus hidup $H$. axyridis dimulai, larva,imago. Lama stadia telur $H$. axyridis 3 hari, larva terdiri dari 4 instar, lama stadia masing-masing instar yaitu instar 1 (2.4 hari), instar 2 (2.4 hari), instar 3 (5 hari), instar 4 (12 hari), dan imago (18.5 hari).

Karakter Daya mangsa tertinggi $H$. axyridis terjadi pada larva instar 4 yaitu daya mangsanya mencapai $428.3 \%$ dari berat tubuhnya dengan jumlah mangsa $9.81 \pm 1.01$ ekor/hari. Preferensi stadia $H$. axyridis pada larva instar 1, 2, dan 3 menyukai kutu $M$. persicae nimfa instar 1 , sedangkan $H$. axyridis larva instar 4 dan imago lebih menyukai $M$. persicae nimfa instar 4

\section{DAFTAR PUSTAKA}

Ahn Y, Kim Y, Yoo J. 2001. Toxicity of herbicide glufosinate-ammonium to predatory insects and mites of Tetranychus urticae (Acari: Tetranychidae) under laboratory conditions. Journal of Economic Entomology. 94:157-161

Anonymous. 2018. Kenali Musuh-musuh Utama pada Tanaman Jeruk. http://www.tanindo.comabdi13hal2401. Diakses tanggal 22 April 2018

Anonymous. $2018^{\mathrm{b}}$. Harmonia axyridis. http://en.wikipedia.org. Diakses tanggal 16 April 2018

Anwar H, Pramono, Djoko, Sularno. 1999. Daya Mangsa Kumbang Coccinellidae arcuata $\mathrm{F}$ terhadap Aphis spp. pada Tanaman Kacang Hijau. Prosiding Seminar Nasional Peranan Entomologi dalam Mengendalikan Hama yang Ramah Lingkungan dan Ekonomis. Perhimpunan Entomologi Indonesia Cabang Bogor.

Chapman RF. 1998. The Insects: Structure and Function. Cambridge University Press.New York. Hal 89-91.

Cho JR, Kim YJ, Kim HS, Yoo JK. 2002. Some biochemical evidence on the selective insecticide toxicity between the two aphids, Aphis citricola and Myzus malisuctus (Homoptera: Aphididae), and their predator, Harmonia axyridis (Coleoptera: Coccinellidae) Journal of Asia-Pacific Entomology. 5:49-53.

Ditlin. 2008. Pengenalan dan pengendalian organisme Penggangu pada tanaman jeruk.http://ditlin.hortikultura.go. Diakses tanggal 11 April 2008

Dreves, Amy J. 1998. New bio control research project in corvallis, Oregon on Harmonia axyridis. Amy J. Derves, INSECTA. 
Hukusima S, Ohwaki T. 1972. Further notes on feeding biology of Harmonia axyridis (Coleoptera: Coccinellidae). Research Bulletin of the Faculty of Agriculture, Gifu University. 33:75-82.

Joon-Ho Lee and Taek-Jun Kang . 2004. Functional response of Harmonia axyridis (Pallas) (Coleoptera: Coccinellidae) to Aphis gossypii Glover (Homoptera: Aphididae) in the Laboratory. Biological Control 31: 306310.

Kalshoven LGE. 1981. The Pests of Crops in Indonesia. Jakarta: P.T Ichtiar Baru

Koch RL 2003. The Multicolored Asian Lady Bettles, Harmonia axyridis: A Riview of its biology, uses in biological control, and non- target impact. In the: Journal of Insect Science. Available online: insectscience.org/3.32. Diakses tanggal 25 April 2018.

Michaud JP. 2002. Invasion of the Florida citrus ecosystem by Harmonia axyridis (Coleoptera: Coccinellidae) and asymmetric competition with a natives pecies, Cycloneda sanguinea. Environmental Entomology. 31:827-835.
Nation JL. 2002. Insect Physiology and Biochemistry. Boca Raton London. New York. Hal 71-74

Prasetyo, Kukuh R. 2000. Daya Predasi Kumbang Kubah (Coccinellidae) terhadap Kutu Daun (Aphididae). Skripsi tidak ditebitkan. Malang: Universitas Negeri Malang

Sitrianingsih. 2008. Harmonia axyridis sebagai Agen Pengendali Hayati. http://www.lpp.uns.ac.id .Diakses tanggal 15 Juni 2018

Tarumingkeng. 2007. Serangga dan lingkungan. IPB.

Wagiman FX. 2006. Pengendalian Hayati Hama Kutu Perisai Kelapa dengan Predator Chilocorus Politus. Yogyakarta: Gadjah Mada University Press. Hal 104-107

Xue Y, Bahlai CA, Frewin A, Sears MK, Schaafsma AW, Hallett RH. 2009. Predation by Coccinella septempunctata and Harmonia axyridis (Coleoptera: Coccinellidae) on Aphis glycines (Homoptera: Aphididae). Environ. Entomol. 38(3):708-714. 